\title{
Role of Methane Capture for Sustainable Biodiesel Production from Palm Oil: A Life Cycle Assessment Approach
}

\author{
Hermawan Prasetya ${ }^{\#}$, Yandra Arkeman*, Erliza Hambali ${ }^{1}$ \\ \# Center of Policies Assessment for Technology Diffusion, The National Agency for Assessment and Application of Technology (BPPT), \\ Management Building, 2th floor, Puspitek, Serpong, Indonesia \\ E-mail: hermawanprasetya@gmail.com
}

* Agroindustrial Technology Department Bogor Agricultural University (IPB), Indonesia

E-mail: yandra_ipb@yahoo.com

${ }^{1}$ Surfactant and Bioenergy Research Center (SBRC) Bogor Agricultural University (IPB), Indonesia

E-mail:erliza.h@gmail.com

\begin{abstract}
Palm Oil Mill Effluent (POME) is one of the major wastes generated by palm oil milling which is a part of palm oil diesel production chain. POME contain of methane (about 60-70 \%), which contribute to Greenhouse Gas (GHG) Emission. Due to reduction GHG emission is one of indicator bioenergy sustainability, some alternatives have been implementing to reduction it. One of the alternatives is implementing of methane capture technology which able to capture and/or utilize it for energy source. In this paper, Life Cycle Assessment (LCA) was employed to identify role of methane capture technology in sustainability of palm oil biodiesel production. By employed cradle to gate LCA on biggest producer of palm oil biodiesel in Indonesia, GHG emission is $23.00 \mathrm{~g}$ CO2eq per Mega Joule (MJ) biodiesel production with methane capture, and $40.79 \mathrm{~g}$ CO2eq per MJ biodiesel without methane capture. From this result, it was concluded that implementation of methane capture could reduce GHG emission significantly (more than $70 \%)$.
\end{abstract}

Keywords—biodiesel; GHG Emission; methane capture

\section{INTRODUCTION}

Biodiesel is one of alternative energy which have been getting a lot of attention recently (Yee et al., 2009). Biodiesel has several advantages than conventional diesel in terms of GHG emission and availability (Yee et al., 2009; Queiroz et al., 2012), also using of biodiesel contribute on foreign currency savings for the country and the job generation in rural areas and industries (Queiroz et al., 2012).

In Indonesia, there are more than 20 plants which are potential as feedstock for biodiesel production. Recently, palm oil (Elaeis guineensis) is best choice as biodiesel feedstock, because palm oil have some advantages such as palm oil is relatively cheap price if it is compared to other vegetable oils (Panapanaan et al., 2009; Growth, 2011), planting cycle of palm oil is about 25 years, including 23 productive years, and the average yearly production per hectare for well managed plantations is 19.1-20.1 (average 19.6) tons of fresh fruit bunches (Reijnders and Huijbregts, 2008), and rendement of oil from palm oil is 20-29\% (Manurung, 2001; Reijnders and Huijbregts, 2008). Also, continuity of palm oil supply for biodiesel production cand be mantained, because it have been cultivated in large areas. In 2010, palm oil plantation area was 8,1 million hectares with avarage annulay growth was $11,8 \%$. In 2009 , crude palm oil was aproxiatelly 20,2 million ton with anually icreasing was $12 \%$. In 2020, it is predicted that crude palm oil in Indonesia will be 40 million ton (Kemenperin, 2011).

The production of palm oil is not without problems or challenges (Panapanaan et al., 2009). Palm oil cultivation have been blamed as a culprit for deforestation, loss of biodiversity, endangering wild animals and species, soil, air and water pollution, chemical contamination (Panapanaan et al., 2009; Sheil et al., 2009; Lam and Lee, 2011). At the milling factories, the problems of waste and pollution particularly of the palm oil mill effluents (POME) (Panapanaan et al., 2009; Poh and Chong, 2009).

Both deforestation and POME are contributed in Greenhouse Gas (GHG) emission, which reduction the emission launched as an indicator of sustainability or biofuel standard. Deforestation, especially on land clearing activity contributes highest carbon dioxide (CO2) emission in 
biodiesel production chain (Hartono and Irsyad, 2011; Hidayatno et al., 2011), and POME contribute on biomethane (CH4) emission (Poh and Chong, 2009). Some technologies have been implemented to reduce GHG emission. One of them is methane capture which implemented to capture and/or utilize it for energy source.

The purpose of this paper is to identify the role of methane capture on reduction of GHG emission in ensuring sustainability of palm oil biodiesel production. Life cycle assessment of palm oil biodiesel production was employed to predict environmental impact especially GHG emission from the production. Simple if than analysis was implemented to compare production with and without methane capture.

\section{A. Production Palm Oil Biodiesel}

Oil palm contributed to Indonesia economic significantly. Oil palm is an important exported agricultural commodity from Indonesia. In 2010, exported of CPO and its derivative product was 15.7 million ton (Growth, 2011; Kemenperin, 2011). In 2008, it was estimated, 6 million labours were employed in palm oil estates (Goenadi, 2008), and number of employers who worked in palm oil industries were 1.7 to 2 million peoples (Growth, 2011).

Palm Oil milling industries extract Fresh Fruit Bunch (FFB) and produce Crude Palm Oil (CPO) and Palm Kernel Oil (PKO). CPO is produced through process sterilization, striping, pressing and purification, while process of depricarping, nut cracking and pressing produce palm kernel oil (PKO) (Poh and Chong, 2009; SBRC, 2009).

Biodiesel is a diesel replacement fuel that is manufactured from vegetable oils, recycled cooking greases or oils, or animal fats (Srivastava and Prasad, 2000; USDE, 2008). The biodiesel manufacturing process converts oils and fats into chemicals called long chain mono alkyl esters, or biodiesel. These chemicals are also referred to as fatty acid methyl esters or FAME (USDE, 2008). Raw or refined vegetable oil, or recycled greases can not used directly as biodiesel, caused mostly by the greater viscosity, or thickness, of the raw oils compared to that of the diesel fuel for which the engines and injectors were designed. Transesterification is common process which implemented to convert raw oil into biodiesel (Dillon et al., 2008; USDE, 2008). Transesterication, also called alcoholysis, is the displacement of alcohol from an ester by another alcohol in a process similar to hydrolysis, except than alcohol is used instead of water. This process has been widely used to reduce the viscosity of triglycerides (Srivastava and Prasad, 2000).

Most of palm oil biodiesel industries in Indonesia use refine palm oil as raw material, only few industries use Palm Fatty Acid Distillate (PFAD). Stearin and PFAD are produced from refinery of CPO. Refinery convert CPO into better quality of edible oil through degumming, bleaching, and deodorization (SBRC, 2009). Palm oil biodiesel production which starts from palm oil cultivation to FAME production. Fresh Fruit Bunch which produced from palm oil cultivation is converted to CPO in palm oil milling plant. The next step, CPO is refined to produce Refined Palm Oil (RPO) as main product and PAFD as by product from the processing. Both RPO and PAFD are used as raw materials in biodiesel production.

\section{B. POME And Methane Capture Technology}

Raw POME is a colloidal suspension containing 95-96\% water, $0.6-0.7 \%$ oil and $4-5 \%$ total solids including $2-4 \%$ suspended solids (Lam and Lee, 2011). POME will be generated from sterilizer condensate, sludge separator and hydrocyclone waste (Poh and Chong, 2009; Lam and Lee, 2011) for each tone $(1.13 \mathrm{~m} 3)$ of crude palm oil processed (Lam and Lee, 2011).

POME has negative and positive sides. In one side, POME is a highly polluting wastewater with high chemical oxygen demand (COD) and biochemical oxygen demand (BOD) in which can caused severe pollution to the environment, typically pollution to water resources. On the other hand, POME was identified as a potential source to generate renewable bioenergy such as biomethane and biohydrogen through anaerobic digestion (Lam and Lee, 2011).

Every 1 tone FFB produce 0.7 ton POME (Sairan and Aman, 2007). POME was mainly consist of biomethane $(\mathrm{CH} 4)$ and carbon dioxide (CO2) in 65:35 ratios (Sairan and Aman, 2007; Lam and Lee, 2011) and approximately $28 \mathrm{~m} 3$ of gases were emitted from 1 ton of POME (Lam and Lee, 2011). In reducing GHG emission from POME, methane capture technology has been implemented in some palm oil milling plants. Also, capturing of methane from POME is directed to use this gas as source of renewable energy, due to highly flammable and combustible characteristic (Sairan and Aman, 2007).

Since POME contains high level of organic matters and thus, adoption of anaerobic digestion in the first stage of the treatment process is a necessity to convert the bulk of the wastes to biogas (biomethane), either applying open pond or open digesting tank systems (Lam and Lee, 2011). Methane which produced by digesting, was captured by covered lagoon or close tank technologies. Biomethane is utilized for some purposes such as flaring, steam production, electricity or Combine Heat and Power (CHP) (EPA, 2011).

\section{METHODOLOGY}

In identification role of methane capture technology in palm oil biodiesel production, we were employed Life Cycle Assessment (LCA) method. LCA is a tool to assess the potential environmental impacts and resources used throughout a product's lifecycle, i.e., from raw material acquisition, via production and use phases, to waste management (ISO14044, 2006). LCA methodology consists of four phases namely goal and scope definition, inventory analysis, impact assessment and interpretation (Hidayatno et al., 2011) .

The goal of the analysis was identification methane capture in palm oil biodiesel production. The scope of analysis was bounded from palm oil cultivation to biodiesel production (cradle to gate). The study analyzed only GHG emission of biodiesel production; other environmental impacts such as toxification, acidification and Eutrophication were not assessed.

The life cycle inventory analysis phase (LCI phase) is the second phase of LCA. It is an inventory of input/output data with regard to the system being studied. It involves the collection of the data necessary to meet the goals of the 
defined study (ISO14044, 2006). LCI of the study was show in Figure 1, where input and output of biodiesel production chain were identified.

Impact assessment of palm oil biodiesel production was calculated by employing general equation below.

$$
\mathrm{E}=\mathrm{A} \times \mathrm{EF}
$$

Where,

$$
\begin{aligned}
\mathrm{E} \quad= & \text { emissions } \\
\mathrm{A} \quad= & \text { activity data (e.g., fuel consumed, material } \\
& \text { input, throughput, or production output) } \\
\mathrm{EF} \quad= & \text { emission factor (usually the weight of the } \\
& \text { pollutant or the unit weight, or the volume or } \\
& \text { duration of the activity). }
\end{aligned}
$$

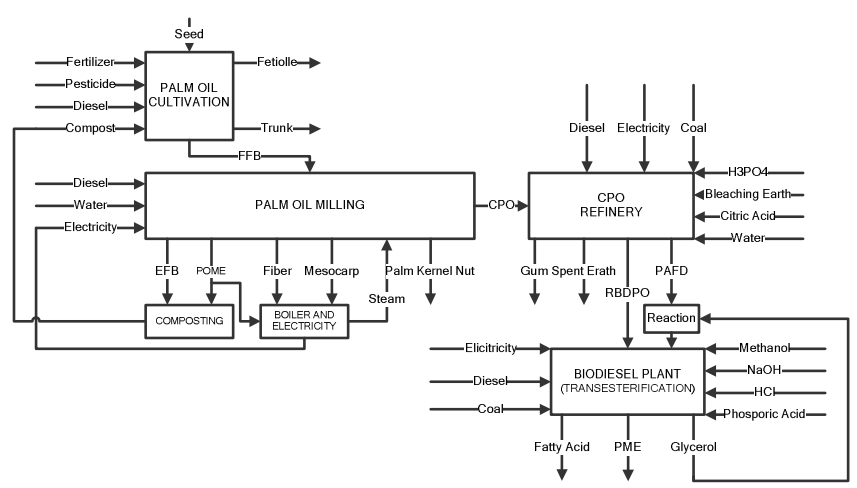

Fig. 1 Life Cycle Inventory of Palm Oil Biodiesel Production

The GHG emission impacts were calculated by using a Biograce-Excel Biofuel GHG Calculation version $4 \mathrm{~b}$ (www.biograce.net). In this spreadsheet all of calculation should be converted into Mega Joule (MJ) biodiesel. Emission factors which employed in this calculation were obtained from RED Annex V.C.5, JEC E-3 Database and IPCC. Also, the study took place in a biodiesel company which contributed more than $50 \%$ of total national capacity of biodiesel plant. The location of the company is in Riau Province.

Identification role of methane capture in biodiesel production was conducted a simple IF Analysis. We conducted GHG Calculation with and without implementation of methane capture in biodiesel production. The role identified by comparison of GHG emission per MJ biodiesel production with and without methane capture.

\section{RESULT AND DISCUSSION}

\section{A. Description of Production Data}

In 2011, palm oil estate area in Indonesia was 8.430.036 hectares (ha) and production of fresh fruit bunch (FFB) reached 19.760.011 tons. Among all the provinces in Indonesia, Riau is the one having the largest amount of land where oil palm is cultivated. Oil palm plantations in Riau Province accounted for 2.103.174 hectares in 2011 and production of FFB was 6.293.542 tons.

In the selected company of oil palm cultivation, three main equipments require diesel fuel. These are vehicles, power generators and heavy machinery. Fuel consumption for oil palm cultivation was obtained by collecting data in selected companies. In GHG emission calculation, diesel fuel consumption was obtained by data collection in selected company. Diesel consumption per year of this company was 86.6 liters per year per hectare. Also, from same sources of data, pesticide application takes place at a rate of $0.4 \mathrm{~kg}$ per hectare.

The selected palm oil milling plant processed 277,002.132 ton per year (both from own estates and suppliers) and produced 58,991.357 ton CPO per year. In producing of the amount of CPO, palm oil milling plant consumed 95,799 KWH per year of grid electricity, 106,486 litters per year diesel (for diesel generator and transportation) and 2,934.29 $\mathrm{kg}$ per year raw water. Also, the calculation included emission from transportation EFB to plantation area and CPO to refinery plant. This plant produced palm kernel (nut) was 49,114,134.16 ton per year. Total distance travelled of transportation EFB to plantation was 103,964 kilometres and consumed 27,871 litters, and total distance of CPO transportation from Milling to refinery plant was 245,616 kilometers with total consumed of diesel was $68,266,60$ liters.

Refinery plant produced 1,616,308.2911 tones Refine palm Oil (RPO) from 703,687.613 tones CPO in 2011. Total electricity consumption was $11,621,620 \mathrm{KWH}$ and consumption of bleaching earth was $11,689,727$ tones. Production of FAME was $542,438.54$ tones from 547,593.036 tones RPO. Some inputs per MJ biodiesel were show as follow.

TABLE I

SOME INPUTS PER MJ BIODIESEL PRODUCTION

\begin{tabular}{|l|l|l|l|}
\hline No & \multicolumn{1}{|c|}{ Input } & \multicolumn{1}{|c|}{ Unit } & Amount \\
\hline 1 & Electricity input & {$[$ MJ electricity / MJ biodiesel $]$} & 1.930 \\
\hline 2 & Methanol & {$[\mathrm{kg}$ chemical / MJ biodiesel $]$} & 2.996 \\
\hline 3 & Phosphoric acid & {$[\mathrm{kg}$ chemical /MJ biodiesel $]$} & 0.016 \\
\hline 4 & Hydrochloric acid & {$[\mathrm{kg}$ chemical /MJ biodiesel $]$} & 0.312 \\
\hline 5 & Sodium hydroxide & {$[\mathrm{kg}$ chemical / MJ biodiesel $]$} & 0.979 \\
\hline
\end{tabular}

Sources: PT Wilmar Biodiesel Indonesia Report, 2011

\section{B. GHG Calculation With and Without Methane Capture}

GHG calculation was conducted by employing a spreadsheet which developed by Biograce. The calculation was divided in three groups, i.e.: cultivation of palm oil, processing and transportation. In calculation with methane capture, it was assumed that methane capture able to trap $89 \%$ of total methane (EPA, 2011). The result of GHG emission calculation was show in Table 2.

TABLE III

Calculation of GHG Emission With and Without Methane CAPTURE IN GRAM $\mathrm{CO}_{2 \mathrm{EQ}}$ PER MJ BIODIESEL PRODUCTION

\begin{tabular}{|l|c|c|}
\hline \multicolumn{1}{|c|}{ Activities } & \multicolumn{2}{|c|}{ Methane Capture } \\
\hline & With & Without \\
\hline${\text { Cultivation } \mathbf{e}_{\mathbf{e c}}}$ & & \\
\hline$\cdot \quad$ Cultivation of FFBs & 7.71 & 7.71 \\
\hline$\quad$ Storage of FFB & - & - \\
\hline Processing $_{\mathbf{p}}$ & & \\
\hline
\end{tabular}




\begin{tabular}{|ll|c|c|}
\hline$\cdot \quad$ Extraction of oil & 4.69 & 22.48 \\
\hline$\cdot \quad$ Refining of vegetable oil & 8.38 & 8.38 \\
\hline$\cdot \quad$ Esterification & 1.36 & 1.36 \\
\hline Transport $\mathrm{e}_{\mathrm{td}}$ & & \\
\hline$\cdot \quad$ Transport of FFB & 0.16 & 0.16 \\
\hline$\cdot \quad$ Transport of Oil & - & - \\
\hline$\cdot \quad$ Transport of FAME & 0.25 & 0.25 \\
\hline$\cdot \quad$ Filling station & 0.44 & 0.44 \\
\hline TOTAL GHG Emission & $\mathbf{2 2 . 9 9}$ & $\mathbf{4 0 . 7 8}$ \\
\hline
\end{tabular}

Source: Result of calculation, 2012

Based on Table 2, GHG emission calculation of palm oil biodiesel with methane capture was 22.99 gram $\mathrm{CO} 2 \mathrm{eq}$ per MJ Biodiesel. The result was lower than similar GHG calculations. The Result from two studies on GHG Emission from biodiesel production were $28.41 \mathrm{CO}$ eq per MJ Biodiesel (EPA, 2011) and 26.11 CO2eq per MJ Biodiesel (Hartono and Irsyad, 2011). Also, if landuse change was not included in GHG emission calculation, emission from processing was biggest contribution in biodiesel production chain.

GHG emission without methane capture was nearly two times if compared to emission with methane capture; therefore implementation methane capture in palm oil milling plant was very important project to reduce GHG emission significantly.

\section{CONCLUSIONS}

By employed cradle to gate LCA on biggest producer of palm oil biodiesel in Indonesia, GHG emission is $23.00 \mathrm{~g}$ CO2eq per Mega Joule (MJ) biodiesel production with methane capture, and $40.79 \mathrm{~g} \mathrm{CO}$ eq per MJ biodiesel without methane capture. From this result, it was concluded that implementation of methane capture could reduce GHG emission significantly (more than $70 \%$ ).

The recommendation from result of study was methane capture should be implementation in all of palm oil milling oil in reduction of GHG emission from palm oil biodiesel production. It was need a financial studies in implementation of methane capture in palm oil milling, also study on identification of government incentives or supports in this implementation.

\section{REFERENCES}

[1] Dillon, H.S., Laan, T., Dillon, H.S, Biofuels - At What Cost : Government support for ethanol and biodiesel in Indonesia. The Global Subsidies Initiative (GSI), of the International Institute for Sustainable Development (IISD) Geneva, Switzerland, December 2008.
[2] EPA, Memorandum To Air and Radiation Docket EPA-HQ-OAR2011-0542 on Calculation of Lifecycle GHG Emissions Related to Renewable Fuels from Palm Oil-Based Biodiesel and Renewable Diesel, 2011

[3] Goenadi, D.H, Perspective On Indonesian Palm Oil Production. Paper presented on the International Food \& Agricultural Trade Policy Council's Spring 2008 Meeting, 12 May 2008, Bogor, Indonesia, 2008

[4] Growth, W, Prospek Dan Arah Pengembangan Agribisnis Kelapa Sawit Di Indonesia. Laporan World Growth, Februari 2011.

[5] Hartono, Irsyad, M.I.A, Perhitungan Emisi Biodiesel Dari Kelapa Sawit Sebagai Bahan Bakar Untuk Pembangkit Listrik Tenaga Diesel. Ketenagalistrikan Dan Energi Terbarukan Vol. 10 No. 2 Desember 2011 hal : $75-86,2011$.

[6] Hidayatno, A., Zagloel, T.Y.M., Purwanto, W.W., Carissa, Anggraini, L, Cradle To Gate Simple Life Cycle Assessment Of Biodiesel Production In Indonesia. Makara, Teknologi, Vol. 15, No. 1, April 2011: 9-16, 2011.

[7] ISO14044, Environmental Management — Life Cycle Assessment - Requirements and Guidelines. ISO copyright office Case postale 56, CH-1211, Geneva, 2006

[8] Kemenperin, Industri Hilir Kelapa Sawit, 2011

[9] Lam, M.K., Lee, K.T, Renewable and Sustainable Bioenergies Production from Palm Oil Mill Effluent (POME): Win-win Strategies Toward Better Environmental Protection. Biotechnology Advances 29 (2011) 124-141, 2011

[10] Manurung, E.G.T, Analisis Valuasi Ekonomi Investasi Perkebunan Kelapa Sawit di Indonesia. Environmental Policy and Institutional Strengthening IQC-PCE-I-806-96-00002-00, 2001

[11] Panapanaan, V, Helin, T., Kujanpää, M., Soukka, R., Heinimö, J., Linnanen, L, Sustainability Of Palm Oil Production And Opportunities For Finnish Technology And Know-How Transfer. Lappeenranta University of Technology, Faculty of Technology, LUT Energy, 2009

[12] Poh, P.E., Chong, M.F, Development of Anaerobic Digestion Methods for Palm Oil Mill Effluent (POME) Treatment. Bioresource Technology 100 (2009) 1-9, 2009

[13] Queiroz, A.G., Franc, L., Ponte, M.X, The Life Cycle Assessment of Biodiesel from Palm Oil ("dende ") in the Amazon. Biomass and Bioenergy 36 (2012) 50-59, 2012

[14] Reijnders, L., Huijbregts, M.A.J, Palm Oil and the Emission of Carbon-Based Greenhouse Gases. Journal of Cleaner Production 16 (2008) 477e482, 2008

[15] Sairan, S., Aman, M.I, CO2 Reduction Opportunities - Power Generation Perspectives. Research Paper on TNB Research Sdn. Bhd., No. 1, Jalan Ayer Itam, Kawasan Institusi Penyelidikan Bandar Baru Bangi, 43000 Kajang, Selangor, Malaysia, 2007.

[16] SBRC, Analisis dan Prospek Industri Hilir Kelapa Sawit Indonesia. Laporan Akhir, Pusat Penilitian Surfaktan dan Bioenergi IPB, Bogor, 2009

[17] Sheil, D., Casson, A., Meijaard, E., Noordwijk, M.v., Gaskell, J., Sunderland-Groves, J., Wertz, K., Kanninen, M., 2009. The impacts and opportunities of oil palm in Southeast Asia : What do we know and what do we need to know? Occasional paper no. 51. CIFOR, Bogor, Indonesia, 2009

[18] Srivastava, A., Prasad, R, Triglycerides-Based Diesel Fuels. Renewable and Sustainable Energy Reviews 4 (2000) 111 133 , 2000

[19] USDE, Biodiesel Handling and Use Guideline. U.S. Department of Energy Office of Scientific and Technical Information P.O. Box 62 Oak Ridge, TN 37831-0062, 2008

[20] Yee, K.F., Tan, K.T., Abdullah, A.Z., Lee, K.T, Life Cycle Assessment of Palm Biodiesel: Revealing Facts and Benefits for Sustainability. Applied Energy 86 (2009) S189-S196, 2009 